\title{
Counting of ${ }^{32}$-Labeled Ribonucleic Acid Utilizing Cerenkov Radiation
}

\author{
Shigeki Mizuno*, Hoshio Eguchi, Keiji Yano and \\ Hikoyuki YamaguCHI \\ Laboratory of Radiation Genetics, Faculty of Agriculture, \\ The University of Tokyo, Tokyo
}

\section{Introduction}

Hard beta-emitters which have beta-particles with the energy larger than $0.265 \mathrm{MeV}$ are subjects of direct counting, without using any scintillator systems, via Cerenkov radiation ${ }^{1,2)}$ in aqueous solutions using a commercially available liquid scintillation spectrometer. Counting conditions by this method were studied in detail by $\mathrm{Haberer}^{3)}$ with ${ }^{137} \mathrm{Cs},{ }^{204} \mathrm{Tl}$, ${ }^{40} \mathrm{~K},{ }^{90} \mathrm{Sr},{ }^{90} \mathrm{Y},{ }^{144} \mathrm{Ce},{ }^{144} \mathrm{Pr}$, and ${ }^{106} \mathrm{Rh}$, and by Braunsberg and Guyver ${ }^{4}$ with ${ }^{24} \mathrm{Na}$ and ${ }^{32} \mathrm{P}$. Recently, Clausen ${ }^{5)}$ also applied this method to counting ${ }^{32} \mathrm{P}$-orthophosphate $\left({ }^{32} \mathrm{Pi}\right)$, and it was suggested by these studies that this method was useful in determining the radioactivities of various biological compounds labeled with ${ }^{32} \mathbf{P}$. Bolton, et al. ${ }^{6)}$ applied this method for the determination of the elution profile of ${ }^{32} \mathbf{P}$-labeled bacterial DNA fragments from the hydroxyapatite column. Their application was based on the following useful features of this method: samples can be counted without drying and without being adulterated, and valuable materials can be reprocessed.

In this paper, we will describe the application of "Cerenkov counting"6) for measuring ${ }^{32} \mathbf{P}$-labeled ribonucleic acid ( $\left.{ }^{32} \mathrm{P}-\mathrm{RNA}\right)$. The present study showed that the ${ }^{32} \mathrm{P}-\mathrm{RNA}$, not only in the high molecular weight form, but also in the hydrolyzed form, could be counted in aqueous solutions without being affected by quenchers, carriers, and high concentrations of salts and sugar, in a wide range of sample volumes. The ${ }^{32} \mathrm{P}-\mathrm{RNA}$ adsorbed on a membrane-filter was also counted satisfactorily by this method.

\section{Materials and Methods}

$2 \cdot 1$ Preparation of ${ }^{32} \mathbf{P}$-labeled RNA

Pseudomonas schuylkilliensis strain $P$ was grown at $30^{\circ} \mathrm{C}$ with aeration for $3 \mathrm{hr}$ and 15 min to the mid-log phase in the nutrient broth-polypeptone medium $(8 \mathrm{~g}$ nutrient broth (Difco) $+5 \mathrm{~g}$ polypeptone per 1 liter of distilled water, $\mathrm{pH}$ 6.8) containing $0.33 \mathrm{mCi}$ (per 13.5 $\mathrm{m} l$ of the medium) of carrier-free ${ }^{32} \mathrm{Pi}$ (The Radiochemical Centre, Amersham, England). Cells from $27 \mathrm{~m} l$ of the culture were harvested by centrifugation $(10,000 \times \mathrm{g}, 5 \mathrm{~min})$ in the cold, suspended in $10 \mathrm{ml}$ of $5 \times 10^{-2} M$ Tris- $\mathrm{HCl}$ (pH 7.4) containing $10^{-2} M \mathrm{MgCl}_{2}$ and $0.5 \mathrm{mg} /$ $\mathrm{m} l$ bentonite ${ }^{7}$, and subjected to sonic oscillation $(10 \mathrm{kc}, 7 \mathrm{~min})$. To the sonicate, $0.3 \mathrm{~m} l$ of $20 \%$ sodium lauryl sulfate (SLS) and an equal volume of phenol saturated with $0.1 \mathrm{M}$ acetate buffer ( $\mathrm{pH}$ 6.0) and containing $0.1 \%(\mathrm{w} / \mathrm{v})$ of 8 -hydroxyquinoline were added. The mixture was stirred at room temperature $\left(29^{\circ} \mathrm{C}\right)$ for 60 $\mathrm{min}$, then was centrifuged $(8,000 \times \mathrm{g}, 15 \mathrm{~min})$ in the cold, and the water layer was separated. Nucleic acids were precipitated by adding $2 \%$ sodium acetate and 2 volumes of $99.5 \%$ ethanol. After letting the mixture stand over-night at $-20^{\circ} \mathrm{C}$, the precipitate was collected by centrifugation $(3,000 \mathrm{rpm}, 10 \mathrm{~min})$ in the cold. The precipitate was dissolved in $1.0 \mathrm{ml}$ of $10^{-2} M$ Tris- $\mathrm{HCl}\left(\mathrm{pH} 7.4\right.$ ) containing $5 \times 10^{-3} M$ $\mathrm{MgCl}_{2}$ and was dialyzed against $500 \mathrm{ml}$ of the same buffer for $1.5 \mathrm{hr}$, being stirred at room temperature. After the dialysis, $50 \mu \mathrm{g}$ of

* Present Address: Division of Enzymology, Institute of Applied Microbiology, The University of Tokyo, Tokyo. 
deoxyribonuclease $(1 \times$ cryst. beef pancreas, Worthington Biochem. Corp.) was added and the mixture was incubated for $30 \mathrm{~min}$ at room temperature. Then $50 \mu \mathrm{g}$ of pronase $\mathrm{E}$ (KakenKagaku Co., Tokyo, self-digested at $37^{\circ} \mathrm{C}$ for $2 \mathrm{hr}$ ) was added and the mixture was incubated for another $30 \mathrm{~min}$ at room temperature.

The mixture was shaken for $5 \mathrm{~min}$ with an equal volume of phenol (saturated with acetate buffer, containing 8-hydroxyquinoline) in the presence of $0.8 \mathrm{mg}$ of bentonite, and was centrifuged $(3,000 \mathrm{rpm}, 20 \mathrm{~min})$ in the cold.

From the water-layer, RNA was precipitated by adding sodium acetate and ethanol as stated above, and was dissolved in $1.0 \mathrm{~m} l$ of distilled water. This solution was applied on a column $(1.2 \mathrm{~cm} \times 26 \mathrm{~cm})$ of Sephadex G-50 (coarse), eluted with distilled water, and the first portion of the excluded material monitored both by U.V. absorption and radioactivities was collected and used throughout the experiment as ${ }^{32}$ P-RNA. This preparation (total volume $=26 \mathrm{~m} l$, total amount of RNA $=1.46 \mathrm{mg}$ ) showed a typical U.V. absorption spectrum of RNA: $\mathrm{A}_{250 \mathrm{~m} \mu} / \mathrm{A}_{260 \mathrm{~m} \mu}=0.521, \quad \mathrm{~A}_{230 \mathrm{~m} \mu} / \mathrm{A}_{260 \mathrm{~m} \mu}=0.405$. Ninety-three per-cent of the radioactivity of this fraction was precipitable in the presence of cold 5\% trichloroacetic acid (TCA), and 99.6\% of it became cold TCA- soluble after incubating with $100 \mu \mathrm{g} / \mathrm{m} l$ of ribonuclease (cryst., salt-free, Worthington Biochem. Corp., pre-incubated at $80^{\circ} \mathrm{C}$ for $10 \mathrm{~min}$ ) at $37^{\circ} \mathrm{C}$ for $30 \mathrm{~min}$, and $99.8 \%$ of it became cold TCAsoluble after being hydrolyzed with $0.3 \mathrm{~N} \mathrm{KOH}$ at $37^{\circ} \mathrm{C}$ for $18 \mathrm{hr}$.

\section{$2 \cdot 2$ RNA and protein carriers}

Carrier RNA $(3.1 \mathrm{mg} / \mathrm{m} l)$ was prepared from the liver of trout, Oncorhynchus nerka, by the SLS-bentonite-phenol method, which will be stated in another report. Albumin (egg, $5 \times$ cryst., Nutritional Biochemicals Corp.) dissolved in $5 \times 10^{-2} M$ Tris- $\mathrm{HCl}$ (pH 7.4) was used as a carrier protein.

\subsection{Hydrolysis of RNA}

A mixture of $28 \mu \mathrm{g}$ of ${ }^{32} \mathrm{P}-\mathrm{RNA}$ and $310 \mu \mathrm{g}$ of the carrier RNA in the total volume of 2.0 $\mathrm{ml}$ was hydrolyzed under one of the following conditions: $0.3 \mathrm{~N} \mathrm{KOH}, 37^{\circ} \mathrm{C}, 18 \mathrm{hr} ; 1 \mathrm{~N} \mathrm{HCl}$, $100^{\circ} \mathrm{C}, 1 \mathrm{hr} ; 5 \% \mathrm{TCA}, 100^{\circ} \mathrm{C}, 15 \mathrm{~min}$; and $5 \%$ perchloric acid (PCA), $100^{\circ} \mathrm{C}, 15 \mathrm{~min}$.

2.4 Paper-chromatography of the alkaline hydrolysate of ${ }^{32} \mathbf{P}-\mathrm{RNA}$

The ${ }^{32} \mathrm{P}-\mathrm{RNA}$ was hydrolyzed by $0.3 \mathrm{~N} \mathrm{KOH}$ at $37^{\circ} \mathrm{C}$ for $18 \mathrm{hr}$, neutralized by $\mathrm{PCA}$ and the salt was precipitated by centrifugation. The supernatant was applied on a sheet of chromatographic paper $(40 \mathrm{~cm} \times 40 \mathrm{~cm}$, Toyo Filterpaper Co., Tokyo, No. 51) and developed twodimensionally using the following solvent systems: 1) isobutyric acid-1 $\mathrm{N}$ NH $\mathrm{NH}_{4} \mathrm{OH}-0.1 \mathrm{M}$ $\mathrm{Na}_{2}$-EDTA (10:6:0.16, by volume), descending, 2) methanol-ethanol-conc. $\mathrm{HCl}$-water $(25: 12.5$ : $3: 9.5$, by volume), ascending. Four $2^{\prime},\left(3^{\prime}\right)-$ mononucleotide spots were located under the U.V. lamp. Each spot was cut into 2 to 4 pieces, put into a counting vial, and the radioactivity was determined via Cerenkov radiation without adding any solvent.

\subsection{Adsorption of RNA on a membrane-} filter

The mixture of ${ }^{32} \mathrm{P}-\mathrm{RNA}(5.6 \mu \mathrm{g})$ and the carrier RNA $(93 \mu \mathrm{g})$ in $3.0 \mathrm{ml}$ of $5 \%$ TCA was placed in ice for $10 \mathrm{~min}$, then passed through a membrane-filter (diameter: $3.0 \mathrm{~cm}$, Millipore HAWP, mean pore size: $0.45 \mu$ ) which was prewashed with $5 \mathrm{ml}$ of cold $5 \%$ TCA- $10^{-2} M$ phosphate buffer (pH 6.7), and washed with $5 \mathrm{~m} l$ of the same cold TCA-phosphate three times. Under these conditions, 93\% of the radioactivities was adsorbed on the filter. The filter was dried at $80^{\circ} \mathrm{C}$ for $30 \mathrm{~min}$ before counting. When various amounts of ${ }^{32} \mathrm{P}$-RNA were adsorbed, 0.02 to $0.3 \mathrm{ml}$ of samples were taken from the mixture of 0.8 $\mathrm{m} l$ of ${ }^{32} \mathrm{P}-\mathrm{RNA}$ and $0.24 \mathrm{~m} l$ of the carrier RNA. Total volume of each sample was adjusted to $3.0 \mathrm{ml}$ with phosphate buffer $(\mathrm{pH}$ 6.7) and TCA giving final concentrations of $8 \times 10^{-3} M$ and $5 \%$ respectively. Filtration was performed as mentioned above.

2.6 Liquid scintillation spectrometer and scintillator systems

A Tri-Carb 3375 (Packard Instrument Co. Inc.) was used throughout the experiment. The high voltage of the instrument was adjusted to give $47.7 \%$ of the counting efficiency for the ${ }^{3} \mathrm{H}$-standard (Packard K0412, 121,600 dpm, 9 May 1966, in toluene with 2,5-dipheny- 
loxazole (PPO) and 1,4-bis-2-(5-phenyloxazolyl)benzene (POPOP)) at a gain of $50 \%$ with a window setting of $50 \sim 1,000$.

The following three scintillator systems were used: 1) Bray's system ${ }^{8)}$ : POPOP was replaced by dimethyl-POPOP (1,4-bis-2-(4-methyl-5-phenyloxazolyl)-benzene). 2) Toluenetriton system: PPO $5 \mathrm{~g}$, dimethyl-POPOP $0.3 \mathrm{~g}$, triton X-100 $333 \mathrm{~m} l$, toluene $667 \mathrm{ml}$. 3) Toluene system: PPO $5 \mathrm{~g}$, dimethyl-POPOP $0.3 \mathrm{~g}$, toluene $1,000 \mathrm{ml}$.

\section{Results}

3.1 Counting of ${ }^{32} \mathrm{P}-\mathrm{RNA}$ in solution

The ${ }^{32} \mathrm{P}-\mathrm{RNA}$ dissolved in $1.0 \mathrm{~m} l$ of distilled water was counted via Cerenkov radiation. As shown in Fig. 1-A, the maximum counting efficiency was given at gains between 30 and $50 \%$ with a window setting of $50 \sim 1,000$. At a gain of $30 \%$ with a window setting of $50 \sim$ $1,000,{ }^{32} \mathrm{Pi}$ in $1.0 \mathrm{~m} l$ of $10^{-2} M$ phosphate buffer (pH 6.7) gave a counting efficiency of $22 \%$
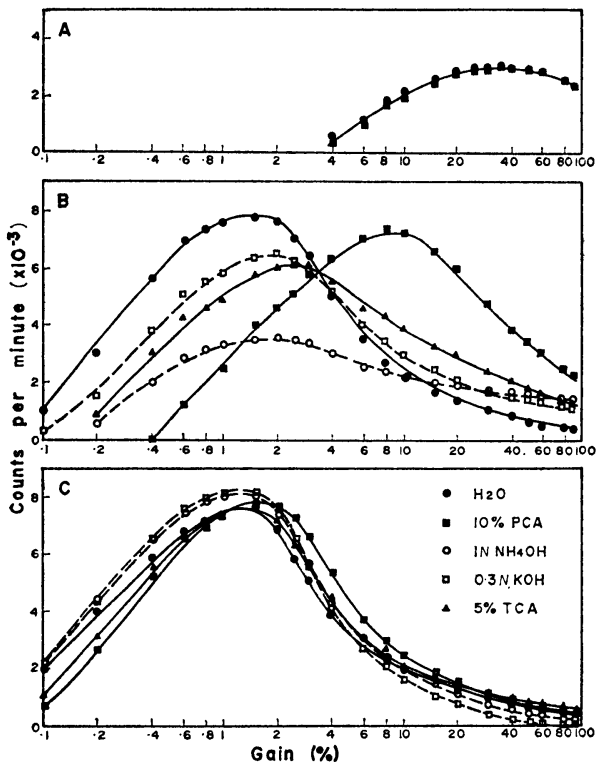

Fig. 1 Effect of quenchers on the counting of ${ }^{32}$ P-RNA. A: Cerenkov counting, B: with $10 \mathrm{ml}$ of Bray's system, C: with $10 \mathrm{ml}$ of the toluene-triton system. Window setting, $50 \sim 1,000$, in each case. To $0.1 \mathrm{ml}$ of the ${ }^{32} \mathrm{P}-\mathrm{RNA}, 0.9 \mathrm{ml}$ of quencher, as indicated, was added. In A, effects of two quenchers are indicated, points obtained by three other quenchers were either in-between or overlapped. (by the Cerenkov counting). A window setting of $50 \sim 1,000$ was used throughout the experiment, although the energy spectrum of the above ${ }^{32} \mathrm{P}-\mathrm{RNA}$ sample showed that most of the count $(99.7 \%)$ was recovered in the window width of $50 \sim 800$. The counting of ${ }^{32} \mathrm{P}-\mathrm{RNA}$ via Cerenkov radiation was not affected (Fig. 1-A) by acids (10\% PCA, 5\% TCA) and alkalis ( $\left.1 \mathrm{~N} \mathrm{NH}_{4} \mathrm{OH}, 0.3 \mathrm{~N} \mathrm{KOH}\right)$, while, as compared in Figs. 1-B and 1-C, when the ${ }^{32} \mathrm{P}$-RNA sample was counted in the presence of a scintillator system (Bray's system or toluene-triton system), both the maximum counting efficiency and the gain position yielding the maximum counting efficiency were affected by these quenchers.

As shown by Clausen ${ }^{5}$ for the counting of ${ }^{32} \mathrm{Pi}$, the Cerenkov counting of ${ }^{32} \mathrm{P}-\mathrm{RNA}$ was affected by sample volume. Between 5 and 11 $\mathrm{m} l$ of the sample volume the counting efficiency reached the maximum, and $88.3 \%$ and $79.7 \%$ of the maximum value (at $7 \mathrm{ml}$ ) was obtained when the sample volume was $1 \mathrm{~m} l$ and $20 \mathrm{~m} l$ respectively. When samples of a constant volume $(2.0 \mathrm{~m} l)$ were prepared, good proportional counting was obtained between $0.152 \mathrm{mg}$ and $3.648 \mathrm{mg}$ of the RNA content (Fig. 2).

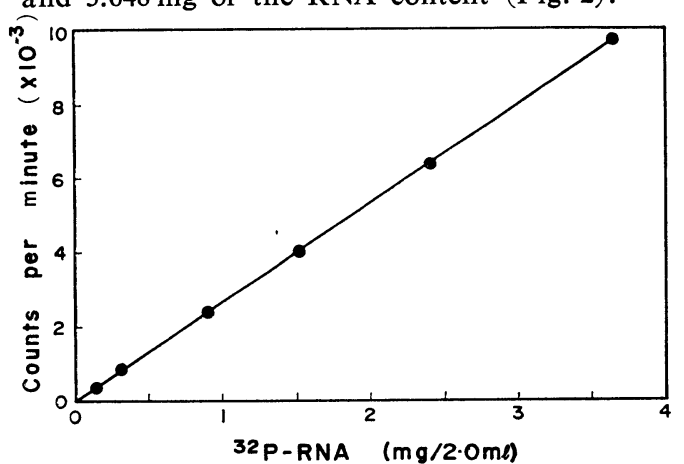

Fig. 2 Effect of RNA concentration on the Cerenkov counting. From the mixture of $0.1 \mathrm{ml}$ of the ${ }^{32} \mathrm{P}-\mathrm{RNA}$ and $5.0 \mathrm{~m} l$ of the carrier RNA, samples containing various amounts of RNA, as indicated, were taken, and the total volume in a vial was adjusted to $2.0 \mathrm{ml}$ with distilled water. Window setting, 50 1,000. Gain, $35 \%$.

Additions of carrier RNA $(0.004 \sim 10.230 \mathrm{mg})$, protein $(0.5 \sim 10.0 \mathrm{mg}), \mathrm{KCl}$ or $\mathrm{NaCl}(0.19 \sim 1.90$ $M$ ), and sucrose (2.9 28.6\%) showed very little effect (the maximum difference from the no- 
addition control value was $6.5 \%$ when 10.23 mg RNA was added) on the counting of ${ }^{32} \mathbf{P}$ RNA via Cerenkov rediation (Figs. 3-A $~ 3-C)$.
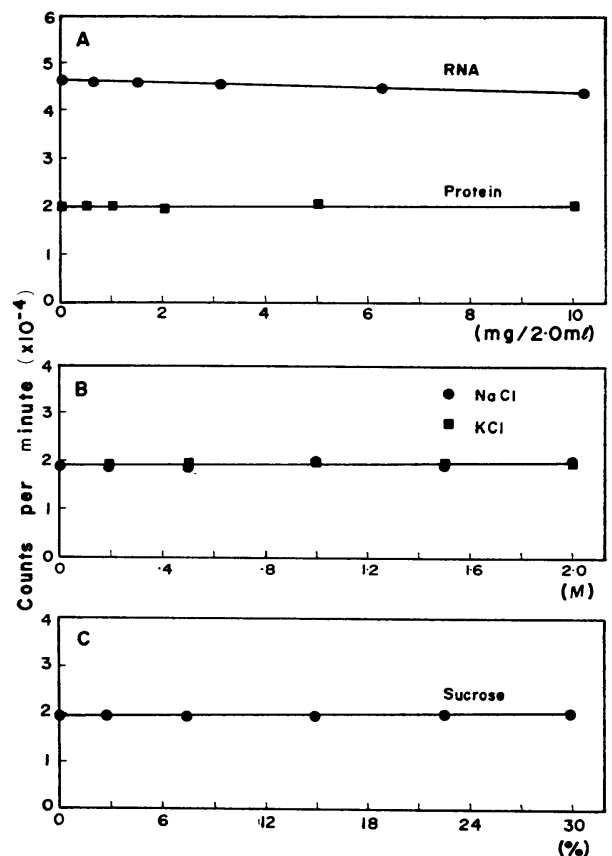

Fig. 3 Effects of RNA and protein carriers, salts and sucrose on the counting of ${ }^{32} \mathrm{P}-\mathrm{RNA}$ via Cerenkov radiation. To $0.1 \mathrm{~m} l$ of the ${ }^{32} \mathrm{P}-\mathrm{RNA}$, various materials were added to obtain final concentrations as indicated. Total volume was adjusted to $2.0 \mathrm{ml}$ with $0.05 M$ Tris- $\mathrm{HCl}$ ( $\mathrm{pH}$ 7. 4) for protein, and with distilled water for others. Window setting, $50 \sim 1,000$. Gain, $40 \%$.

Table 1 Counting of ${ }^{14} \mathrm{C}$ and ${ }^{3} \mathrm{H}$ with or without scintillator

\begin{tabular}{ccccc}
\hline & $\begin{array}{c}\text { Cerenkov } \\
\text { counting }\end{array}$ & \multicolumn{2}{c}{$\begin{array}{c}\text { +Toluene-triton } \\
\text { scintillator } \\
\text { system }(10 \mathrm{ml})\end{array}$} \\
\hline $\begin{array}{c}\text { Discriminator } \\
\text { setting } \\
\text { Gain (\%) }\end{array}$ & $50-1,000$ & \multicolumn{2}{c}{$50-1,000$} \\
\hline${ }^{14}$ C-L-leucine & 40 & 10 & 40 \\
${ }^{3}$ H-adenosine & $\left(\right.$ counts $/ \mathrm{min}^{\mathrm{b}}$ & $26^{\mathrm{c}}$ & 231,190 & - \\
background $^{\mathrm{b}}$ & 14 & - & 532,540 \\
\hline
\end{tabular}

a. ${ }^{14} \mathrm{C}$-L-leucine (generally labeled) $0.02 \mathrm{ml}+$ $1 \mathrm{~N} \mathrm{NH}{ }_{4} \mathrm{OH} 1.0 \mathrm{~m} l$

b. ${ }^{3} \mathrm{H}$-adenosine (generally labeled) $0.01 \mathrm{ml}+$ $5 \%$ PCA $1.0 \mathrm{~m} l$

c. background counts are included.
Approximately 1.2 times better counting efficiency was obtained when a polyethylene vial was used instead of a glass vial. ${ }^{3} \mathrm{H}$ and ${ }^{14} \mathrm{C}$ gave essentially no count under the condition used for the Cerenkov counting as indicated in Table 1.

\subsection{Counting of ${ }^{32}$ P-RNA in hydrolyzed forms}

${ }^{32}$ P-RNA hydrolyzed either by alkali or acid could also be counted via Cerenkov radiation. Those hydrolyzed RNA samples gave the maximum counting efficiency at the same gain range-i.e. $35 \sim 50 \%$-as with that of the nonhydrolyzed ${ }^{32}$ P-RNA with a window setting of 50-1,000. When various amounts of hydrolyzed samples were counted via Cerenkov radiation or by adding Bray's scintillator system, the linearity of the counts vs. amounts of sample was better with the Cerenkov counting (Fig. 4).

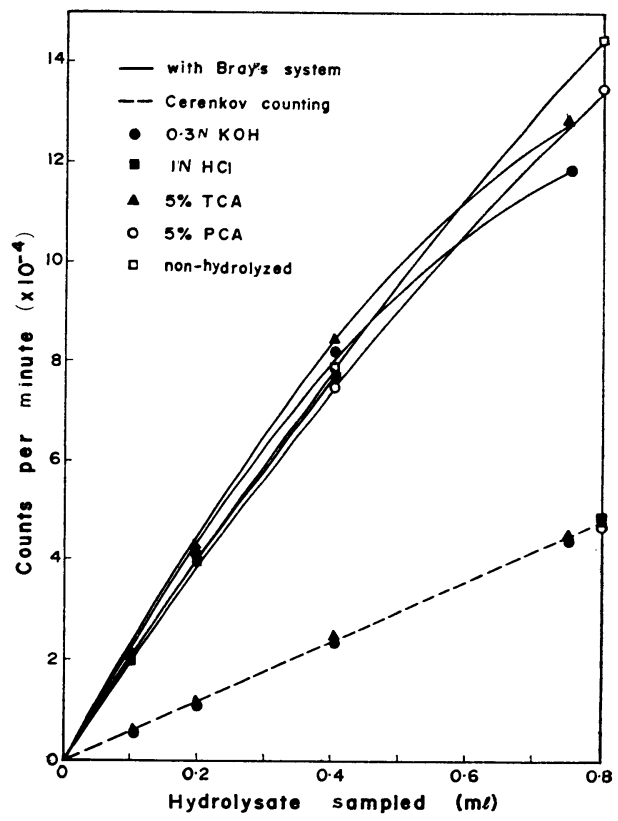

Fig. 4 Counting of ${ }^{32} \mathrm{P}-\mathrm{RNA}$ in hydrolyzed forms. Sample volume was adjusted to $2.0 \mathrm{~m} l$ with distilled water. Window setting, $50 \sim 1,000$. Gain, $40 \%$ for the Cerenkov counting, $1.5 \%$ for the counting with Bray's system $(10 \mathrm{ml})$. As to Cerenkov counting, each point on the graph consists of overlapped points of nve different conditions. 


\subsection{Counting of ${ }^{32} \mathrm{P}-\mathrm{RNA}$ adsorbed on a membrane-filter}

The ${ }^{32}$ P-RNA adsorbed on a membranefilter in the presence of 5\% TCA demonstrated to be counted without adding any solvent. As shown in Fig. 5, the gain range giving the maximum counting efficiency was $40 \sim 50 \%$ with a window setting of $50 \sim 1,000$. When the filter-paper was immersed in toluene, higher counts were obtained with shift of the gain position $(20 \sim 30 \%)$, and again, counts were affected by the volume of toluene: $20 \mathrm{~m} l$ was the best in this case.

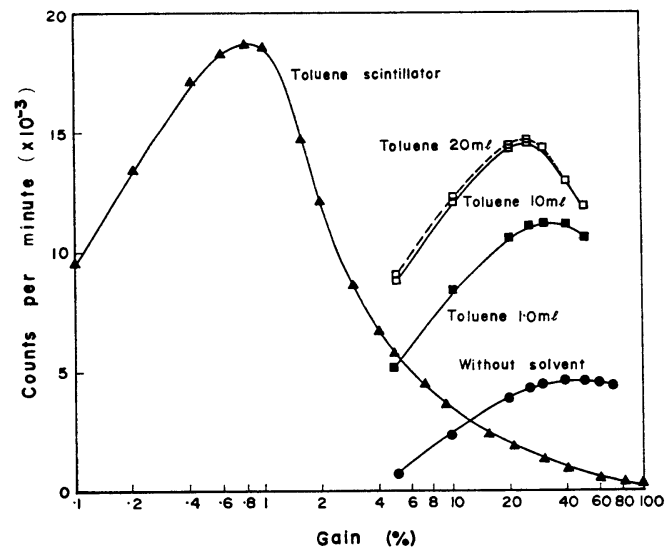

Fig. 5 Counting of ${ }^{32} \mathrm{P}-\mathrm{RNA}$ adsorbed on a membrane-filter. A membrane-filter which adsorbed the ${ }^{32} \mathrm{P}-\mathrm{RNA}$ was cut into four pieces, and a piece was put on the bottom of a glass counting-vial. Counting was performed without adding solvent or with toluene as indicated or with $10 \mathrm{ml}$ of the toluene scintillator system. Window setting, 50 1,000 .

When the filter-paper was immersed in 99.5 $\%$ ethanol, 5\% TCA and 5\% PCA respectively, lesser counts were obtained than in toluene: counts with solvent $(10 \mathrm{ml}) /$ counts without solvent $=3.03$ (toluene), 2.00 (ethanol), $1.56(5 \%$ TCA) and 1.68 (5\% PCA). No elution of ${ }^{32} \mathrm{P}$ RNA into toluene was observed, but significant amounts of ${ }^{32} \mathrm{P}-\mathrm{RNA}$ were eluted into other solvents: per cent elution was 0 (toluene), 3.6 (ethanol), 34.2 (5\% TCA) and 59.7 (5\% PCA).

As shown in Fig. 5, at each peak condition, counts obtained without adding solvent were $25.0 \%$ and those obtained by adding $20 \mathrm{ml}$ of toluene were $75.2 \%$ of those obtained by add- ing toluene-scintillator system.

When various amounts of ${ }^{32}$ P-RNA (14.4 $216 \mu \mathrm{g})$ were adsorbed on a membrane-filter, satisfactorily linear relationships between counts and amounts of ${ }^{32} \mathrm{P}-\mathrm{R}$ NA were obtained by either of the above counting systems. Furthermore, when several pieces of membranefilter each of which adsorbed ${ }^{32}$ P-RNA were counted in a vial, good coincidence with calculated values (the summation of separate countings of each piece) was demonstrated (Fig. 6), suggesting that, as far as these numbers of pieces were concerned, the geometry of a piece of filter-paper in a vial did not affect the counting efficiency very much.

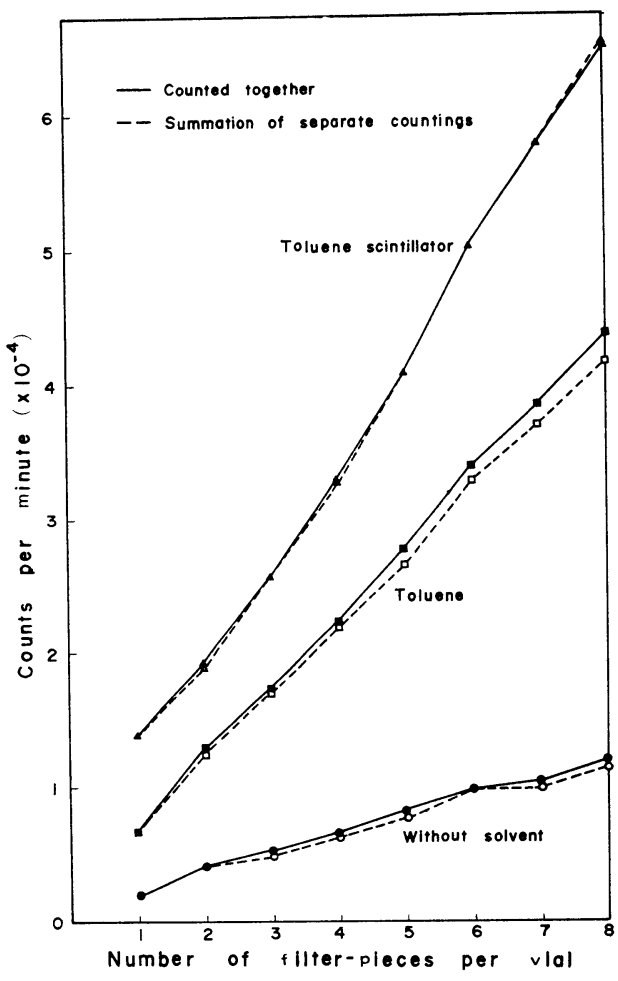

Fig. 6 Counting of several pieces of membranefilter carrying ${ }^{32} \mathrm{P}-\mathrm{RNA}$. One membranefilter which adsorbed the ${ }^{32} \mathrm{P}-\mathrm{RNA}$ was cut into four pieces. These pieces were counted separately or several pieces were counted together in a glass vial as indicated. Window setting, $50 \sim 1,000$. Gain: $40 \%$, without solvent; $30 \%$, with $10 \mathrm{ml}$ of the toluene; $0.8 \%$, wtih $10 \mathrm{ml}$ of the toluene scintillator system.

When the filter-paper carrying ${ }^{32}$ P-RNA was counted without adding solvent in poly- 
ethylene vials, approximately 1.5 times higher counts were obtained than in glass vials (window setting, 50 1,000, gain, 50\%).

This method was applied for determination of radioactivities of four $2^{\prime},\left(3^{\prime}\right)$-mononucleotide spots on the paper-chromatograph of the alkaline hydrolysate of the ${ }^{32}$ P-RNA. The data in Table 2 indicated that $96.5 \%$ of the radioactivities applied was recovered as mononucleotides, and the base composition of the ${ }^{32} \mathrm{P}-\mathrm{RNA}$ calculated by the distribution of radioactivities reasonably resembled those of ribosomal RNA, the bulk of cellular RNA.

Table 2 Cerenkov counting of ${ }^{32} \mathrm{P}-2^{\prime}$, $\left(3^{\prime}\right)$-mononucleotides adsorbed on a chromatographic paper

\begin{tabular}{|c|c|c|c|}
\hline \multirow[b]{2}{*}{$\begin{array}{l}\text { Spot on the } \\
\text { chromatograph }\end{array}$} & \multirow[b]{2}{*}{$\underset{\min ^{a}}{\operatorname{counts}}$} & \multicolumn{2}{|c|}{ Base compositions } \\
\hline & & ${ }^{32} \mathrm{P}-\mathrm{RNA}^{\mathrm{b}}$ & $\begin{array}{l}\text { Ps. schuylkil } \\
\text { liensis riboso- } \\
\text { mal RNA }\end{array}$ \\
\hline & & \multicolumn{2}{|c|}{ (mole \%) } \\
\hline Adenylic acid & 1,382 & 25.9 & 25.4 \\
\hline Guanylic acid & 1,697 & 31.8 & 31.7 \\
\hline Uridylic acid & 1,128 & 21.1 & 21.5 \\
\hline Cytidylic acid & 1,130 & 21.2 & 21.4 \\
\hline
\end{tabular}

Total radioactivity

recovered as

mononucleotides 5,337

Total radioactivity

applied 5, 530

${ }^{32} \mathrm{P}$ as mononucleotides

$96.5 \%$

a. gain $40 \%$, discriminator $50 \sim 1,000$, background counts $(16 \mathrm{cpm})$ were subtracted.

b. calculated from the distribution of counts, assuming that ${ }^{32} \mathrm{P}$ was incorporated uniformly.

\section{Discussion}

The present studies revealed that ${ }^{32} \mathrm{P}$-labeled RNA either in solution or adsorbed on a membrane filter could be counted quantitatively via Cerenkov radiation. Acids, alkalis, salts, sucrose, protein, and RNA had no, or very little, quenching effects, thus samples could be counted at their maximum counting efficiencies with a fixed setting of gain and window width (ex. 40\%, 50 1,000). ${ }^{32}$ P-RNA of high molecular weight forms fractionated by the sucrose gradient sedimentation or column chromatographies, or ${ }^{32}$ P-RNA hydrolyzed under various acidic or alkaline conditions would be good subjects of counting by this method. As the counting efficiency was affected by the sample volume, it is necessary to make samples of the same volume in a set of experiments. The counting efficiency of ${ }^{32} \mathbf{P}$ obtained by the Cerenkov counting was approximately $20 \%$ and is roughly an equivalent level with that obtained by a thin-window gas flow counter. ${ }^{14} \mathrm{C}$ and ${ }^{3} \mathrm{H}$ gave essentially no count under the conditions of the Cerenkov counting. It is, therefore, useful in doublelabeling experiments ${ }^{32} \mathbf{P}$ and ${ }^{14} \mathbf{C}$, or ${ }^{32} \mathbf{P}$ and ${ }^{3} \mathrm{H}$ ) to use this method first to determine the radioactivity due to ${ }^{32} \mathbf{P}$. The counting of ${ }^{32} \mathrm{P}$ RNA or its hydrolysate adsorbed on a membrane-filter or on a chromatographic paper via Cerenkov radiation will have advantages in the following cases, when samples are required to be eluted for further studies, or when samples are adsorbed with quenchers such as some chromatographic solvents, or in doublelabeling experiments.

Counting of ${ }^{32} \mathrm{P}-\mathrm{RNA}$ adsorbed on a filterpaper in a glass or polyethylene vial without adding any solvent can not be due to the Cerenkov radiation in air, bacause $\beta(=v / c$, where $v$ is the velocity of the $\beta$-particle, and $c$ the velocity of light), is calculated as 0.973 for ${ }^{32} \mathrm{P}$, by the following equations: $\beta=\sqrt{\left(m c^{2}\right)^{2}-\left(m_{0} c^{2}\right)^{2}} / m c^{2}$, $m c^{2}=T_{e}+m_{0} c^{2}=1.71+0.51(\mathrm{MeV})$, where $m c^{2}$ is the total energy of electron, $T_{e}$ the maximum kinetic energy of $\beta$-particle of ${ }^{32} \mathrm{P}$, and $m_{0}$ the mass of electron. Thus, $n$, the index of refraction of the medium, should be greater than 1.027 as $n>1 / \beta$ is required to cause the Cerenkov radiation, but $n$ of air at atmospheric pressure is 1.00029. Thus, it is most likely to assume that the counting is due to the Cerenkov radiation in glass or polyethylene of counting vials caused by escaped $\beta$-particles of ${ }^{32} \mathbf{P}$ through filter-paper and air. Yield of photons by the Cerenkov radiation is affected not only by $n$ but also by the path length of electrons in the medium ${ }^{1,2)}$, thus higher counts would be expected by using polyethylene vials or by immersing a filter-paper in solvents. The volume effect on the Cerenkov counting in 
solution could also be explained from the balance between electrons converted to photons by the Cerenkov radiation in a solvent and material of vials and electrons or emitted Cerenkov lights absorbed in those media.

\section{Summary}

${ }^{32} \mathbf{P}$-labeled RNA was quantitatively counted via Cerenkov radiation, without adding any scintillator solvent, using a liquid scintillation spectrometer. This method could be applied to the counting of ${ }^{32} \mathrm{P}-\mathrm{RNA}$ of high molecular weight form or hydrolyzed form either in solution or adsorbed form on a filter-paper. The counting efficiency, approximately $20 \%$ in solution, was practically not affected by acids, alkalis, salts, sucrose, protein, and carrier RNA. The sample volume was shown to be a factor which affected the counting efficiency.

\section{Acknowledgments}

The authors wish to thank Dr. S. Tano of the same laboratory for his cooperation in preparing the carrier RNA, and Professor A. Kusumegi, Institute for Nuclear Study, the University of Tokyo, for his valuable discus- sions. The Author's appreciation also is due to Mr. G.J. Richards, Packard Instrument International S.A., for his careful reading the manuscript.

\section{References}

1) Jelley, J.V.: "Cerenkov Radiation and Its Applications", Pergamon Press, London, New York, Paris, Los Angeles (1958)

2) Ritson, D.M.: In "Techniques of High Energy Physics" (D.M. Ritson, ed.), p.301, Interscience Publishers, Inc., New York (1961)

3) Haberer, K.: Atomwirtschaft, 10, 36 (1965)

4) Braunsberg, H., and Guyver, A.: Anal. Biochem., 10, 86 (1965)

5) Clausen, T.: Anal. Biochem., 22, 70 (1968)

6) Bolton, E.T., Brenner, D.J., Britten, R.J., Cowie, D.B., Falkow, S., Kohne, D.E., Rake, A., and Roberts, R.B.: Ann. Report of the Director Dept. of Terrestrial Magnetism, Carnegie Inst., p. 68 (1968)

7) Fraenkel-Conrat, H., Singer, B., and Tsugita, A.: Virology, 14, 54 (1961)

8) Bray, G.A.: Anal. Biochem., 1, 279 (1960), 